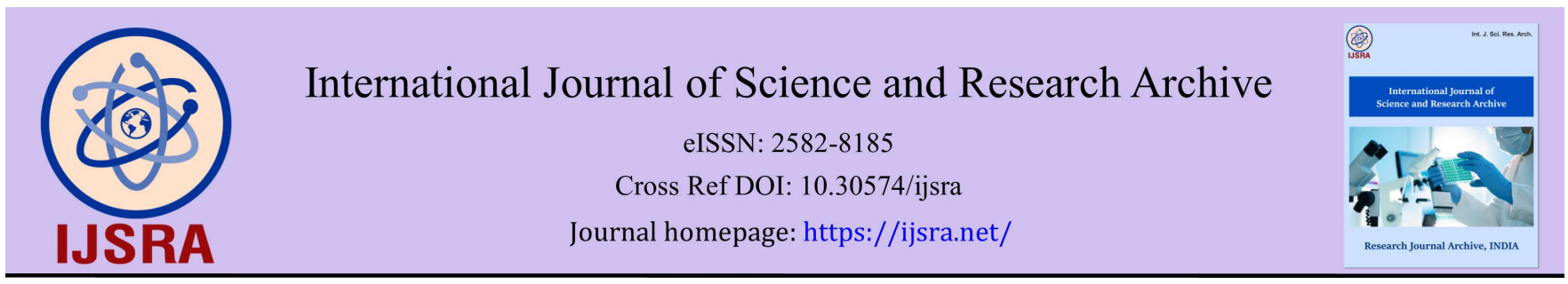

(CASE REPORT)

\title{
Holistic approach in covid-19 phobia causing near missing ectopic pregnancy treatment
}

\author{
Eddy Hartono ${ }^{1,}{ }^{*}$, Ary Rizqi Rachman ${ }^{2}$, Nuraini Abidin ${ }^{1}$, and Ajardiana Idrus ${ }^{1}$ \\ ${ }^{1}$ Division of Social Obstetrics and Gynecology, Department of Obstetrics and Gynecology, Hasanuddin University, \\ Makassar, South Sulawesi, Indonesia \\ ${ }^{2}$ Department of Obstetrics and Gynecology, Hasanuddin University, Makassar, South Sulawesi, Indonesia
}

International Journal of Science and Research Archive, 2021, 02(02), 057-065

Publication history: Received on 07 March 2021; revised on 12 April 2021; accepted on 15 April 2021

Article DOI: https://doi.org/10.30574/ijsra.2021.2.2.0052

\begin{abstract}
Ectopic pregnancy is one of the major cause of death in the first trimester of pregnancy. Complications may result from misdiagnosis, diagnosis delay, or mistreatment. COVID-19 is currently became pandemic. There is still no specific recommendations for manage pregnant women with COVID - 19. Mrs. EF, 34 y.o., G2P1011 admitted to Wahidin Sudirohusodo Hospital Makassar referred from Hermina Hospital dianosed with missed abortion and suspected of COVID-19 infection. She was first refused to undergo COVID - 19 screening and diagnostic test, though finally agree to proceed with examination. She was definitively diagnosed with ectopic pregnancy following 4 days of undetermined COVID - 19 status. Emergency explorative laparotomy was then performed. This is a maternal near miss case. Delay in performing COVID - 19 examination may compromise management of true emergency obstetrics situation. COVID-19 phobia is one factor that describe excessive fear and anxiety about the transmission of corona virus among health workers. Health workers may be reluctant in treating patient because of undetermined status of COVID-19 causing diagnosis delay.
\end{abstract}

Keywords: Ectopic preganancy; COVID-19 phobia; Near missed

\section{Introduction}

Ectopic pregnancy poses threat to women at reproductive age. It is the leading cause of death in the first trimester of pregnancy in the United States, accounting for $9 \%$ of all deaths in pregnancy. Ectopic pregnancy occurs in $1 \%$ of all pregnancies and $90 \%$ cases occured in the ampula of fallopian tube. It may also arise from the ovaries, cervix, or abdominal cavity.1

Many factors may predispose to ectopic pregnancy. Theoretically, any process that interferes with the embryo's migration into the endometrial cavity may lead into an ectopic pregnancy. Obstruction occurs in half of cases. Obstruction may result from chronic inflammation, intrauterine pathology, endometriosis, or infection. Complications of ectopic pregnancy may result from misdiagnosis, diagnosis delay, or mistreatment. The worst complication of an ectopic pregnancy is uterine or tubal rupture, which can lead to massive bleeding, shock, and death.2,3

Coronavirus disease 2019 (COVID-19) is currently became pandemic spreading almost all over the world, caused by one of beta coronavirus family called Severe Acute Respiratory Syndrome Coronavirus-2 (SARS-COV2) virus. South Sulawesi currently ranks 4th in Indonesia with 10,895 cases and 343 deaths and 7691 cases treated as shown in latest data on August 15, 2020. The effect of COVID-19 infection in pregnancy and fetus is not widely studied and there is still

\footnotetext{
${ }^{*}$ Corresponding author: Eddy Hartono

Division of Social Obstetrics and Gynecology, Department of Obstetrics and Gynecology, Hasanuddin University, Makassar, South Sulawesi, Indonesia.
}

Copyright (C) 2021 Author(s) retain the copyright of this article. This article is published under the terms of the Creative Commons Attribution Liscense 4.0. 
no specific recommendations for manage pregnant women with COVID-19. There is currently no data that shows an increased risk of miscarriage associated with COVID-19. Case reports from previous studies with SARS and MERS did not show any association between infection and risk of miscarriage or second trimester fetal death.4,5

The COVID-19 pandemic is a non-natural disaster that ultimately affect mental well-being and psychosocial health conditions. Women and health workers are more vulberable to experience various psychological distress. Many health workers have been reported to be infected with COVID-19. This circumstance lead to health workers fear of being infected with COVID 19 especially in treating cases of pregnancy with COVID - 19. This may lead to delay in pregnancy management resulted in increased maternal and neonatal morbidity and mortality. 6

\section{Case Report}

Mrs. EF, 34 y.o., G2P1 admitted to Wahidin Sudirohusodo Hospital Makassar on July 1, 2020. She was referred from Hermina Makassar Hospital with Stage 1 Acute Kidney Injury (AKI) + Moderate Anemia + Missed Abortion + Suspected of COVID-19 infection. Her COVID-19 IgG was positive in Hermina Hospita. At Wahidin Sudirohusodo Hospital, she was first treated by internal medicine deparment and then consulted to the Obstetrics and Gynecology Department.

The general status and vital signs of the patient were unremarkable. Both conjunctivas were anemic. Physical and bimanual examination was unremarkable. The patient first began with COVID - 19 screening protocol. The laboratory results showed hemoglobin $6.7 \mathrm{~g} / \mathrm{dl}$, leukocytes 36,300 / ul, platelets 226,000 / ul, neutrophils $91.8 \%$, lymphocytes $4.4 \%$, ureum $67 \mathrm{mg} / \mathrm{dl}$, creatinine $2.35 \mathrm{mg} / \mathrm{dl}$, SGOT $85 \mathrm{U} / \mathrm{L}$, SGPT $74 \mathrm{U} / \mathrm{L}$, RBG $144 \mathrm{mg} / \mathrm{dl}$, sodium $131 \mathrm{mmol} / \mathrm{l}$, potassium $6 \mathrm{mmol} / \mathrm{l}$, chloride $100 \mathrm{mmol} / \mathrm{l}$. Covid $19 \mathrm{IgG}$ and IgM antibody tests were both non-reactive. She was then subjected to have chest CT which showed bilateral pneumonia, bilateral pleural effusion, and gastric tube with a tip impression on the stomach. All patients had to undergone COVID - 19 screening performed by pulmonary colleague. As the patient was suspected to have COVID - 19 infection, she then arranged to have nasopharyngeal swab.

The patient was in has been in her first marriage for 12 years. Her husband was 38 years old. There were no history of menstrual abnormalities, systemic diseases, and surgical intervention. The patient had been in prolonged vaginal discharge and never had any treatment. The patient had just one time antenatal care in Primary health facility during pregnancy. She has one child who currently was 10 years old. She currently work as a housewife and live in a rented house. Her highest educational level was in high school. She came from Kediri, East Java and have been in Makassar for 8 months. Her total family income was Rp. 1,500,000 per month. Patient and family did not adhere to health protocols (rarely use masks).

Oxygenation, antibiotics, analgesics, blood transfusions were administered to improve patient's general condition. Pregnancy termination was arranged by Obstetric Department. Following 2 days of supportive treatment, patient's condition improved. Following laboratory results showed hemoglobin $8.3 \mathrm{~g} / \mathrm{dl}$, leukocytes 7.900 /ul, potassium 4.5 $\mathrm{mmol} / \mathrm{l}$, sodium $140 \mathrm{mmol} / \mathrm{l}$. Nasopharyngeal swab that initially planned was refused by the patient because she strictly refused to be diagnosed with COVID - 19. Her family also did not agree to proceed with nasopharyngeal swab. Moreover, the family finally agreed to proceed with nasopharyngeal swab after being re-educated. Nasopharyngeal swab results subsequently showed negative results.

Following improved patient's conditionsd, Obstetrics Department planned to perform pregnancy termination after conducting an ultrasound examination. Previous ultrasound examination at Hermina Hospital showed an intrauterine pregnancy without the fetal heart rate appropriate to 15 weeks of gestation. This result was consistent with Missed Abortion. Subsequent ultrasound examination in Wahidin Sudirohusodo Hospital showed anteflexion uterus, positive endometrial line, free fluid in the douglass cavity, and an extrauterine fetus with corresponding 15 weeks 5 days of gestational age. This results showed an impression of an ectopic pregnancy. The patient was diagnosed with ectopic pregnancy and moderate anemia arranged to underwent explorative laparotomy. Intraoperatively, a ruptured ectopic pregnancy was encountered in right cornual of fallopian tube. Moreover, there were adhesions between uterus, intestines, and peritoneum. Adhesiolysis and right salpingectomy were performed. Blood transfusions also administered intraoperatively. She was disharged on third postoperative day.

\section{Discussion}

Ectopic pregnancy is a condition in which pregnancy occurs and grows outside the uterine cavity. The fallopian tube, especially the ampullary portion, is the most common site for ectopic pregnancy to occur. Other sites of ectopic pregnancies may occur in other parts of the tube and rarely occur in the ovary, abdominal cavity, amd uterine canal. ${ }^{7}$ 
Ectopic pregnancies occur most frequently in the tubal (97\%), of which 55\% appeared in the ampullary pars, 25\% in the isthmus, and $17 \%$ in the fimbriae. The remaining $3 \%$ are located in the uterus, ovaries, abdominal, and intraligamenter, whereas about $2-2.5 \%$ occur in the cornu of the uterus. ${ }^{7,8}$

Ectopic pregnancy is a health problem for women of reproductive age poses as the leading cause of death in the first trimester of pregnancy in the United States, accounting for $9 \%$ of all deaths in pregnancy. The frequency of ectopic pregnancy is $1 \%$ of all pregnancies. In Great Britain, ectopic pregnancy is still the most common cause of death in first trimester of pregnancy. Nearly 32,000 ectopic pregnancies occur annually in the United Kingdom. In the United States, the annual incidence decreased from 58,178 in 1992 to 35,382 in 1999. In Norway, it is estimated that the incidence of ectopic prefnancy decreases in concordance with decreasing incidence of Pelvic Inflammatory Disease (PID).$^{8}$

The etiology of ectopic pregnancy has been widely investigated, but the exact causes remain unknown. Each pregnancy will begin with fertilization in ampullary portion of fallopian tube, then fertilized ova encounter resistance so that nidation and implantation would remain in the tube. The risk of developing an ectopic pregnancy increases in the presence of several factors, including history of infertility, previous ectopic pregnancy, surgery on the tubes, pelvic infections, exposure to Diethylstil-bestrol (DES), use of IUDs, in vitro fertilization and history of tubal disease. These factors may share a common mechanism which may be anatomical, functional, or both. Certainly, it is very difficult to assess the cause of ectopic implantation in the absence of tube defect. ${ }^{8}$

Ectopic pregnancy is described as the process of implantation of a fertilized ovum, which occurs in the tube the same way as in the uterine cavity. At first, implantation of the fertilized ova occur at the endosalpinx tip or its protruding side. Subsequent zygote development is limited by a lack of vascularization and usually die prematurely. The fertilized ova may be oxidized between two endosalpings in intercolumnar oxidation. It is then separated from the tubal lumen by a layer of tissue that resembles a decidua called the pseudocapsularis. Formation of decidua in the tube is imperfect and the chorial villi easily penetrate the endosalping and into the muscular lining of the tube. This process may damage the tissues and blood vessels. The subsequent development of the fetus depends on several factors, such as the site of implantation, thickness of the tubal wall, and the amount of bleeding that occurs by trophoblast invasion. Under the influence of the estrogen and progesterone released from the corpus luteum and trophoblast, the uterus becomes large and flaccid, and the endometrium also turns into a decidua. Change in the endometrium is called the Arias-Stella phenomenon. Enlarged epithelial cells are essentially hypertrophic, hyperchromatic, lobular, and irregular in shape. The cytoplasm of the cell can be hollow or foamy, and sometimes ther is some mitotic activity. Since the tube is not an ideal environment for the growth of the product of conception, it is not possible for the fetus to grow opitmally as occur in the uterine cavity. Ectopic pregnancy may result in premature death and resorption, tubal abortion or tubal rupture.8,9

The classic clinical features for ectopic pregnancy are the triad of abdominal pain, amenorrhea, and vaginal bleeding. These manifestations are very important in thinking about the diagnosis in patients presenting with pregnancy in the first trimester. However, only 50\% of patients with this ectopic pregnancy presenting with these typical symptoms. Other symptoms may develop are nausea, fatigue, mild abdominal pain, shoulder pain, and a history of recent dyspnoea. The physical examination should focus on vital signs , abdominal, and pelvic examination. Hypotension and tachycardia may result from profuse bleeding due to tubal rupture may not necessarily predict the presence of an ectopic pregnancy although they indicate the need for immediate resuscitation, This conditions may also occur intrauterine pregnancy complications. Normal vital signs do not exclude an ectopic pregnancy. We may find fullness in pouch of Douglas and cervical motion tenderness. The presence of peritoneal signs, cervical motion tenderness, and lateral or bilateral abdominal or pelvic pain raise the suspicion of an ectopic pregnancy. On the other hand, the absence of these signs and symptoms does not exclude an ectopic pregnancy. The presence of an adnexal mass also does not necessarily predict an ectopic pregnancy accurately. Therefore, an ectopic pregnancy should not diagnosed based solely on clinical findings. ${ }^{8,10}$

Laboratory study usually use beta-human chorionic gonadotropin ( $\beta$-hCG) to diagnose pregnancy. $\beta$-hCG is produced by trophoblasts and may be detected in serum approximately 1 week before the next predicted menstruation. If the serum $\beta$-hCG is negative, pregnancy is unlikely. There were very few cases reported confirm ectopic pregnancies with negative $\beta$-hCG. The $\beta$-hCG levels should doubled approximately every 1.4 to 2.1 days until they reached a peak of $100,000 \mathrm{mIU} / \mathrm{ml}$. Quantitative $\beta$-hCG test may be performed serially in differentiating ectopic pregnancy with intrauterine pregnancy. ${ }^{8}$

Definitive diagnosis of an ectopic pregnancy must be assisted by thorough physical, laboratory, and radiological examination. Early diagnosis is mandatory in order to minimize complications of ectopic pregnancy Transvaginal ultrasonography and serial hCG levels are currently the mainstay examination in diagnosing ectopic pregnancy. ${ }^{8,11}$ 
Ectopic pregnancy may be treated surgically or pharmacologically. Conservatif treatment may be performed asymptomatic patients. However, the patient have to adhered to close monitoring. Besides, patients have to accept all risks in case of rupture occur and treated surgically. ${ }^{12}$

Surgical treatment may be performed radically (salpingectomy) or conservatively (usually salpingotomy) and performed by means of laparoscopy or laparotomy. Laparatomy is the preferred technique when the patient is hemodynamically unstable, the operator is not sufficiently trained in laparoscopy, the facilities and supplies for performing laparoscopy are lacking, or there are technical obstacles to perform laparoscopy. In many cases, these patients require salpingectomy because of the extensive damage to the tubes. Hemodynamically stable patient may undergo salpingotomy using a laparoscopic technique. Laparoscopic salpingotomy is indicated in unruptured ectopic pregnancy with size less than $5 \mathrm{~cm}$ in transverse diameter. ${ }^{8,13}$

Medical treatment may avoid surgery and its complication, maintain tubal patency and function, and lower cost. Chemicals that have been studied include hyperosmolar glucose, urea, cytotoxic agents (eg methotrexate and actinomycin), prostaglandins, and mifeproston (RU - 486). Methotrexate is an anti-neoplastic drug that acts as an folic acid antagonist and is a potent apoptosis inducer in trophoblastic tissues. Methotrexate must be administered in hemodinamically stable patients without impaired kidney and liver function. Methotrexate is given in a single dose (50 $\mathrm{mg} / \mathrm{m}^{2} \mathrm{IM}$ ) or by alternative dose of $1 \mathrm{mg} / \mathrm{kg}$ IM on day 1,3,5,7 plus Leucovorin $0.1 \mathrm{mg} / \mathrm{kgBW}$ IM on day 2,4,6, 8. After successful medical treatment, $\beta$-hCG usually disappears from plasma between 14 and 21 days. Treatment is considered failed when there is no decrease in $\beta$-hCG, there is persistent ectopic mass or intraperitoneal bleeding. ${ }^{13}$

Maternal mortality due to ruptured ectopic pregnancy tends to decrease with earlier diagnosis and adequate blood transfusions. Fetus in an ectopic pregnancy may abort. Some women may become infertile after having an ectopic pregnancy or subsequent ectopic pregnancy in another tube. The recurrence rate of an ectopic pregnancy is reported to be between $0-14.6 \%$. With the advancement of existing therapy and earlier diagnosis, the chance for having subsequent pregnancy would be increased. ${ }^{8}$

\subsection{Case analysis based on referal system and risk factor approach}

Poedji Rochyati classified pregnant women into two groups, based on their clinical characteristics, namely: 14

Low risk: those with no problem

High risk, divided into 3 groups, namely:

Group I ( Existing Potential of Obstetric Emergency)

Group II (Existing Obstetrical Treathening Condition)

Group III (Existing Obstetrical Emergency)

In addition to the classification method above, pregnant women can also be grouped based on scoring: 14

Low risk pregnancy : score $=2$

High risk pregnancy : score 6 - 10

Very high risk pregnancy : score $\geq 12$

Based on the risk grouping above, planned referrals are divided into two, namely: ${ }^{14}$

\subsubsection{Early referral planning or Intrauterine referral}

It is early referral planning is carried out for pregnant women with high risk pregnancy criteria and in optimal condition. Referral is intended as an effort to control and prevent further maternal complications. Mothers were referred near term, 38 weeks or more, and there were no signs of labor and complications. This includes a high-risk fetus without an emergency situation. Basically, what is meant by RDB is a term for pregnancy not delivery. 


\subsubsection{Timely Referral}

It is a referral process that must be underwent as a measure to save the lives of mothers and babies. Pregnant women with high risk pregnancy, such as antepartum hemorrhage without anemia and hypovolemic shock, severe preeclampsia/eclampsia and women with early obstetric complications during labor are included in this referral system.

It will only be successful if it is supported by four conditions that can prevent late referral, namely:

Early recognition of danger signs / problems / risk factors, through proactive antenatal screening between provider and client.

Decision making by families regarding preparation and planning for delivery, place and assistant in accordance with the conditions of pregnant women, supported by mental readiness, costs, transportation, and readiness for safe delivery.

Delivery and transportation are immediately carried out, in order to arrive at the referral hospital with the mother and baby still in good condition.

Treatment at the referral hospital must be given immediately by professionals in an effective and efficient manner, both in terms of time and cost.

Late referral is frwuently encountered in referral system. This situation may increase maternal mortality rate. Late referral means: ${ }^{15}$

The condition of the mother and baby is not in optimal condition, may even in a state of critical or emergency.

The time interval to deliver patient from home and hospital is too long.

Immediate management is not provided at the referral hospital.

The analysis in the case above is a near missed case. If we analyze the by using the risk approach system by Poedji Rochjati, this patient fall into High Risk Pregnancy (KRT) criteria, provided the total score is 2 (pregnant women) added with antenatal hemorrhage (score 8) then the total score is included in the category Existing Obstetric Emergency (AGDO) as a prevention of future complication and Timely Referral (RTW) must be taken. In this case, the patient also has a suspected COVID-19 infection, which is a disease with high risk transmission.

In this case, there is a delay in handling the patient at the referral hospital so that diagnosis and action can only be carried out following COVID - 19 screening. This in turn became an obstacle to perform comprehensive management. Patients were not able to undergo USG examinations until they are proven to not have COVID 19. The first diagnosis is solely based on the history and physical examination. The reason for the delay in other patients was due to the lack of knowledge of patients and their families related to COVID - 19. Miscommunication between health providers and the patient's family may delay patient management.

\subsection{Case Analysis based on physiological and sociocultural function of the family}

This case was analyzed with the APGAR family and the SCREEM method. The physiological function of the family is measured by the Family APGAR score. APGAR score is a score used to assess family function from the point of view of each family member regarding their relationship with other family members. APGAR score includes : ${ }^{16}$

Adaptation: In this case, the patient gets full support from her husband and sister

Partnership: There is support from the patient's husband and sister who are willing to exchange ideas / discuss / communicate, and are ready to help the patient (the patient is always accompanied)

Growth: The patient's husband appears to dominate decision making and the patient leaves it completely to her husband.

Affection: Husband and older sister are very concerned about the needs of the patient and always accompany her.

Resolve: Patients often spend time with family. 
The Family APGAR Score in this case is 8. Although it is classified as good, the family factor, in this case the husband, is the major cause for late decision making in terms of informed consent regarding nasopharyngeal swabs.

The sociocultural family was assessed using the SCREEM score with the following details: ${ }^{16}$

Social: Previously the patient lived in East Java then moved to Makassar for the last 8 months

Culture: The patient's husband and family are able to accept the patient's condition and willing to take care of her.

Religious: The patient and her husband are Muslim.

Economic: Patients and their husbands have lower income.

Educational: The patient and husband are both high school graduates.

Medical: Patients and their families already have BPJS for health insurance.

In this case, challenging medical diagnosis related to ectopic pregnancy with suspected COVID - 19 has to overcame by health workers, especially doctors, in order to create adequate communication and delivery of information and education. It is important to know the responses and attitudes of patients and their families to the bad news. The author follows the six steps of the SPIKES protocol, namely: ${ }^{17}$

STEP 1: Prepare for the interview (Setting)

We conducted interviews with this patient when the patient's condition was fully conscious accompanied by her husband and sister in bed with no other patients. We also conducted separate interviews between the patient's older sister and husband.

STEP 2: Assessing the patient's perception (Perception)

From this step it is known that the patient and her husband were reluctant to proceed with surgery because the patient had never previously underwent surgery.

STEP 3: Obtaining trust (Invitation)

At this stage of providing information, we treat ourselves as a caring family as well as professional medical personnel. We provide clear information so that patients and families were willing to listen to medical advice regarding the patient's condition and accept surgical treatment as her priority.

STEP 4: Provide knowledge and information (Knowledge)

Providing information related to this case does not take a long time because the patient, husband, and family leave all decisions regarding the patient's condition and management decided by the patient.

STEP 5: Reply to emotions with an empathetic response (Emotions)

When we provide information, the emotions of the patient, husband and family appear to be controlled.

STEP 6: Strategy and Summary (Strategic)

In this case, the husband and family know the patient's condition. They leave all decisions to the medical personnel, in this case the doctor, to give the best to the patient.

\subsection{Ethical and Medikolegal Analysis}

Bioethics derived from the word bios which means life and ethos which means norms or moral values. Bioethics is an interdisciplinary study in the field of biology and also medical science. ${ }^{18}$ Four ethical principles (beneficence, nonmaleficence, auotonomy, and justice) could be accepted across cultures, but these ethical principles can vary between cultures. ${ }^{19,20}$ There are 4 principles related to bioethics that must always held by a doctor, namely: ${ }^{19}$ 


\subsubsection{Beneficence}

In handling this case the doctor must prioritize the benefits to the patient The patient must have optimal care and nasopharyngeal swab for COVID - 19 screening.

\subsubsection{Non-maleficence}

Every doctor who tries to uphold this principle will avoid any unnecessary treatment and delay related to the patient's condition.

\subsubsection{Autonomy}

In this principle, a doctor is obliged to respect human dignity and rights, especially the right to self-determination. Patients are given the right to think logically and make decisions of their own in terms of surgery and nasopharyngeal swabs. Patient autonomy must be respected ethically. Although initially there was rejection of the nasopharyngeal swab procedure ,the medical personnels must respect the decisions of patients and families.

\subsubsection{Justice}

Justice is the next principle in bioethics. In this case, doctors are prohibited from differentiating their patients based on economic level, religion, ethnicity, social status and so on. Patients are given the same treatment regarding their conditions.

Ethical decision making, especially in clinical situations, may also be done with a different approach from principles above. Jonsen, Siegler and Winslade (2002) developed an ethical theory that uses 4 essential topics in clinical situations, namely : ${ }^{21,22}$

Medical Indication: The patient has received correct information about ruptured ectopic pregnancy and COVID - 19 and appropriate intervention about to performed.

Patient Preferences: Patient's husband was ultimately refused to undergo a nasopharyngeal swab. However, after acquiring suffcient information about patient's condition, he and his family agreed to follow the doctor's recommendation regarding her pregnancy and life - threatening condition.

Quality of Life: Condition that worsen the patient's condition in this case was the time interval from the screening and examination process until the diagnosis was established. However, doctors in every hospital visited by patients have made their utmost efforts to maintain the quality of service

Contextual Features: Family and cultural approach were dominant in our case, where the patient was provided by an understanding of her condition and requires special treatment.

In the perspective of the medical ethics, ethical assessment in medical cases is adjusted to the Indonesian medical code of ethics (KODEKI) issued by the Indonesian Medical Ethics Council (MKEK). In KODEKI, there are 4 responsibilities of doctors especially in treating their patients. The actions of doctors who provide medical information are in accordance with the general responsibilities of articles 7c and 8.23 In addition, in Articles 1 and 2 and Article 13 of the Minister of Health No 585 / MenKes / Per / IX / 1989 regarding medical action / informed consent is consent given by patients or their families based on an explanation of the medical action to be performed to the patients.

Another medicolegal aspect is contained in Law of the Republic of Indonesia Number 29 of 2004 concerning Medical Practice Article 52 of the Republic of Indonesia Law which states that patients, in receiving services in medical practice, have the right: to obtain a complete explanation of medical actions as referred to in Article 45 paragraph (3).

(2) The explanation as referred to in paragraph (2) shall at least include: diagnosis and procedure of medical action, the purpose of the medical action taken, other alternative measures and risks, risks and complications that may occur, prognosis for the action taken. ${ }^{24}$

\subsection{Psychological Analysis}

In March 2, 2020, President of Indonesia, Joko Widodo announced the entry of the COVID-19 virus into Indonesia and there were only two positive corona patients in Indonesia. The announcement immediately shocked entire society, 
moreover, positive cases of COVID-19 were increasing, causing the Government to impose Large-Scale Social Restrictions (PSBB). This pandemic then caused an excessive fear in community or known as coronaphobia.

As known, the word "phobia" is often used to describe the extreme fear of certain objects or conditions that can hinder the sufferer's life. Coronaphobia itself is a terminology used to describe excessive fear and anxiety about the transmission of the corona virus. The form of fear caused by coronaphobia varies from the existence of individual psychological disorders. ${ }^{25}$

Excessive fear to pandemic is not unfamiliar. However, with the development of mass media, it is easier to spread misinformation, add with the sensational news about the pandemic, it has increasingly triggered fear and phobia of the disease. This makes the spread of the "fear virus" faster, even more than the speed at which the "disease virus" spreads. ${ }^{26}$

Coronaphobia can cause psychologic disorders such as levels of distress, excessive avoidance, to functional disorders that are clinically significant to a degree that may require treatment for their emotional disorders. In addition, at a more advanced level, mental disorders can arise in the form of mood disorders, anxiety disorders, to PTSD (post-traumatic stress disorder). ${ }^{27}$

This happened in our case when the patient was given an explanation about COVID 19 and nasopharyngeal swab should be carried out. From this refusal, the process of management of patients was delayed due to the absence of a definitive diagnosis. Health workers would be reluctant in treating patient because of unknown status of COVID - 19. Meanwhile, patients are treated only in regular basis without special rooms and equipment. In combating COVID-19, critical preparation and response were needed, such as equipping health workers and health service facility management with information, procedures, and tools that are essential for safe and effective work. Health workers play an important role in responding to the COVID-19 outbreak. As frontliners, healthcare professionals provide the services needed for patients with suspected and confirmed COVID-19, which are often carried out in challenging circumstances. Officials are at a higher risk of contracting COVID-19 in their efforts to protect the community. Officers can be exposed to hazards such as psychological stress, fatigue, mental fatigue or stigma.

\section{Conclusion}

COVID - 19 pandemic has led the health workers to be extremely cautious in managing every patient admitted to hospital. Holistic and effective approach need to be taken in managing patients in COVID - 19 pandemic especially for emergency cases which may delay management as occurred in our case. Reducing morbidity and mortality as well as protecting health workers should be our priority in treating patients in COVID - 19 pandemic era. This might be accomplished by having efficient standard operating procedures, excellent clinical pathway, and sufficient personal protective equipment.

\section{Compliance with ethical standards}

\section{Acknowledgments}

The Authors would like to thank internal reviewers for suggestions in this manuscripts.

\section{Disclosure of conflict of interest}

There is no conflict of interest in this study

\section{References}

[1] Stulberg D, Cain R Ectopic Pregnancy Rates in The Medical Population American Journal of Obstetric and Gynecology. 2013; 1:p.208-274.

[2] Kurniawan, A and Mutiara, H 'Kehamilan Ektopik Di Abdomen', Medical Profession Journal of Lampung, 2016; 5(2):pp. 5-10.

[3] Tay JI, Moore J, Walker JJ. Ectopic pregnancy. West J Med. 2000; 173(2):131-4.

[4] POGI 'Rekomendasi Penanganan Infeksi Virus Corona (Covid-19) Pada Maternal (Hamil, Bersalin Dan Nifas)', Penanganan Infeksi Virus Corona Pada Maternal, 2020; 1(3):pp. 9-11. 
[5] Situasi virus covid -19 di Indonesia. Available from : https://covid19.go.id

[6] Dukungan, P et al 'Direktorat Jenderal Pencegahan dan Pengendalian Penyakit Kementerian Kesehatan RI Tahun $2020^{\prime}$.

[7] Prawiro, Sarwono, 2007. Ilmu Bedah Kebidanan. PT Bina Pustaka, Jakarta

[8] Puspa, T and Risilwa, M 'Kehamilan Ektopik Terganggu: Sebuah Tinjauan Kasus', Jurnal Kedokteran Syiah Kuala, 2017; 17(1):pp. 26-32

[9] Standar Tatalaksana Medis Rumah Sakit fatmawati. 2002. Kehamilan ektopik Terganggu.Jakarta.

[10] Prawiro, Sarwono, 2007. Ilmu Bedah Kebidanan. PT Bina Pustaka, Jakarta

[11] Buku Panduan Praktis Pelayanan Kesehatan Maternal dan Neonatal. 2002. Kehamilan Ektopik. Yayasan Bina Pustaka Sarwono Prawiroharjo. Jakarta.

[12] Pedoman Diagnosis dan Terapi SMF Ilmu kebidanan dan Penyakit Kandungan, 2008. Edisi III. Rumah Sakit Umum Dokter Soetomo Surabaya.

[13] Wiknjosastro, Hanifa. Kehamilan Ektopik. Ilmu Kebidanan edisi ketiga. Yayasan Bina Pustaka Sarwono Prawiroharjo. Jakarta..hal 1999; 323-338.

[14] Rochjati, P Sistem Rujukan Dalam Pelayanan Kesehatan Reproduksi. Dalam: Bunga Rampai Obstetri dan Ginekologi Sosial. 1st ed. Jakarta. Yayasan Bina Pustaka Sarwono Prawirohardjo: 2005; 258-275

[15] Kementerian Kesehatan RI. 2013. Pelayanan Kesehatan Ibu di Fasilitas Kesehatan Dasar danRujukan.Jakarta: Kementerian Kesehatan RI

[16] Prasetyawati E. 2006. Kedokteran keluarga dan wawasannya. Universitas Sebelas Maret.

[17] Dean A, Willis S 2016. The use of protocol in breaking bad news: evidence and ethos. International Journal of Palliative Nursing 2016; Vol 22, No 6.

[18] Jacobalis S., 2005, Perkembangan ilmu kedokteran, etika medis dan bioetika. Jakarta: Sagung Seto

[19] Beuchamp TL, Childress JF., 2001, The principle of biomedical ethics, ed 3rd. New York: Oxford University Press

[20] Jonsen AR, Siegler M, Winslade WJ., 2002, Clinical ethics: a practical approach to ethical decisions in clinical medicine 5th ed. USA: McGraw-Hill.

[21] Edozien, L C and O'Brien, P M S 2017 Biopsychosocial factors in obstetrics and gynaecology, Biopsychosocial Factors in Obstetrics and Gynaecology. doi: 10.1017/9781316341261.

[22] Kelley MC, Trinidad SB. Silent loss and the clinical encounter: Parents' and physicians' experiences of stillbirth-a qualitative analysis. BMC Pregnancy Childbirth 2012;12:137. doi: 10.1186/ 1471-2393-12-137.

[23] Majelis Kehormatan Etik Kedokteran Indonesia. Kode Etik Kedokteran Indonesia Dan Pedoman Pelaksanaan Kode Etik Kedokteran Indonesia. Kode Etik Kedokteran, 2004

[24] Pemerintah Republik Indonesia. Undang-Undang Nomor 29 Tahun 2004 tentang kesehatan kesehatan. Jakarta .2004

[25] Wheaton, M G, Deacon, B J, McGrath, P B, Berman, N C, \& Abramowitz, J S Dimensions of anxiety sensitivity in the anxiety disorders: Evaluation of the ASI-3. Journal of Anxiety Disorders, 2012; 26(3):401-408 https://doi.org/10.1016/j.janxdis.2012.01.002

[26] Asmundson, G J G, \& Taylor, S Coronaphobia: Fear and the 2019-nCoV outbreak. Journal of Anxiety Disorders, 2020; 70:102196.

[27] Schultz, Carolin \& Powell, Kate \& Crossley, Alison \& Jurkschat, Kerstin \& Kille, Peter \& Morgan, A. \& Read, Daniel \& Tyne, Bill \& Lahive, Elma \& Svendsen, Claus \& Spurgeon, David. Schultz et al 2015 Ecotoxicology review. 2015. 